\title{
COMMENTS
}

\section{OLD STANDARDS IN NEW CONTEXT: A COMPARATIVE ANALYSIS OF FCC REGULATION}

The fact that the nature of broadcasting frequencies necessitates "regulation" to prevent electrical interference ... does not by any stretch of the imagination warrant interference with freedom of speech by supervising broadcasting programs.

\section{- Justin Miller, for the National Association of Broadcasters ${ }^{\mathrm{T}}$}

The Commission's licensing function cannot be discharged, therefore, merely by finding that there are no technological objections to the granting of a license. . . . [C]omparative considerations as to the services to be rendered have [always] governed the application of the standard of "public interest, convenience, or necessity."

- Justice Frankfurter, for the United States Supreme Court ${ }^{2}$

It was thought, for a time, that the regulatory role of the Federal Communications Commission had reached well-defined limits acceptable to the broadcasters and beyond which the Commission would not attempt to expand. During the past decade, however, the Commission has extended the scope of its authority, and the unique cooperation that once existed between this regulatory body and the industry it regulated has disappeared.

During this period the Commission has issued regulations relating to the contracts between stations and the networks; ${ }^{3}$ the publicity to be given to the sale of a station so as to assure a fair price and competitive bidding; 4 the ownership of stations by newspaper publishers; 5 and, most decried by the broadcasting industry, comprehensive program standards with which to evaluate the service rendered by the broadcasters. ${ }^{6}$ The Commission has claimed that its authority

I The Blue Book: An Analysis by Justin Miller, President, National Association of Broadcasters, at I2 (I947).

2 National Broadcasting Co. v. United States, 3 I9 U.S. Igo, 216 (I943).

3 FCC, Report on Chain Broadcasting (I94r). The authority of the rules laid down in this report were upheld by the Supreme Court in National Broadcasting Co. v. United States, 3 I9 U.S. I9O (I943), noted in 4I Mich. L. Rev. Ir95 (I943). Many of the periodicals thought the Commission had gone too far: see Editorial, 216 Saturday Evening Post Ioo (July I7, I943).

4 Powel Crosley, Jr., II F.C.C. 3 (1945). See White, The American Radio I69-72 (1947).

5 Actually, no rules were ever laid down on ownership of stations by newspapers, although an investigation was begun in $194 x .8$ F.C.C. 589 (1941). In x944, a statement of policy was issued by the Commission declaring that the factor of creating a monopoly would be taken into account. FCC Order, Notice of Dismissal of Proceedings, 9 Fed. Reg. 702 (1944). See White, The American Radio I58-59 (1947). A recent case denying a license to a newspaper made no mention of the monopoly element, but only talked of the inexperience of the newspaper in the radio field. WBNX Broadcasting Co., 4 Pike \& Fischer Radio Regulation 207 (r948). (The Pike \& Fischer Radio Regulation service will hereinafter be cited as RR.)

${ }^{6}$ FCC, Public Service Responsibility of Broadcast Licensees (I946), commonly known as the Blue Book. The report has been the subject of a host of legal writings. Excellent discussions can be found in notes in 47 Col. L. Rev. IO4I (1947) and 57 Yale L.J. 275 (I947). 
to undertake these extensive controls is derived from the provisions of the Communications Act of I934 which direct it to issue, renew or revoke broadcasting licenses on the basis of "public interest, convenience, or necessity."7

Persons acquainted with public utility legislation will recognize the familiar "public interest, convenience, or necessity" clause. That this standard, incorporated into the 1934 Act, was borrowed from prior public utility legislation is borne out by the history of the statute. ${ }^{8}$ Whether this borrowing was a result of deliberate identification of the Communications Commission with the earlier utility commissions, or a reflection of a favored device of legislative draftsmanship is not wholly clear. But whatever the motive in the selection of this phrase, one thing is clear-the "public interest, convenience, or necessity" clause has been given a unique interpretation under the Communications Act for the very reason that radio differs in many vital respects from the traditional public utility.

Entry into the power and transportation industries has long required the issuance by the appropriate regulatory commission of certificates of convenience and necessity, consonant with the public interest. While the use of a discretionary standard is thus permitted, under most statutes the applicant has been required to demonstrate actual public convenience and necessity. 9 More signifi-

748 Stat. 1082, 1083, 1085, 1086, 1089 (1934), as amended, 47 U.S.C.A. $\$ \$ 303,307$ (a), $3 \circ 9$ (a), 3 I2(b), 3 I9 (a) (Supp., I949). Section 303 relates to the power and duties of the Commission; section 307 (a) relates to the granting of licenses and allocation of facilities; sections $3^{\circ} 9$ (a) and $3 \mathrm{r} 2$ (b) relate to the issuance, renewal or modification of licenses; section $3 \mathrm{rg}$ (a) relates to construction permits.

The first federal regulation of radio, the Radio Act of Igr2, provided for licensing of broadcasters under the direction of the Secretary of Commerce. 37 Stat. 302 (IgI2). However, the Secretary, Herbert Hoover, was blocked in his attempts to use licensing discretion so as to prevent interference with existing stations. Hoover v. Intercity Radio Co., $286 \mathrm{Fed}$. I003 (App. D.C., I923); United States v. Zenith Radio Corp., I2 F. 2d 6I4 (D.C. Ill., I926). Although these decisions were in accord with the opinion of the Attorney General at the time the Act was passed, 29 Ops. Att'y Gen. 579 (19I2), the result was to create complete disorder, with at least two stations operating on every channel. White, The American Radio I28-30 (I947).

The Radio Act of 1927,44 Stat. II62-II74 (r927), was designed to end this chaos of "free enterprise," and the discretionary standard of "public interest, convenience and necessity" was established. The Radio Act was superseded by the Communications Act of x934, under which all the authority formerly in the Federal Radio Commission was vested in the newly created Federal Communications Commission. 48 Stat. Iror, I102 (1934), 47 U.S.C.A. $\$ \S 601,602$ (Supp. r949).

${ }^{8}$ Senator Dill, floor manager of the legislation, told his colleagues, "In this proposed law, however, we have laid down a basic principle-namely, the principle of public interest, convenience, and necessity - which is the general legal phrase used regarding all public utilities engaged in interstate commerce." 68 Cong. Rec. 3027 (I927). For an excellent history of the phrase as used in state and federal public utility legislation, see Caldwell, The Standard of Public Interest, Convenience or Necessity as Used in the Radio Act of 1927, I Air L. Rev. 295 (1930).

9 See Public-Convenience Application of Atlanta \& St. A.B. R. Co., 7 I I.C.C. 784 (I922); Yazoo \& M.B.R. Co. v. Public Service Commission, I70 La. 44r, I28 So. 39 (I930); Seaboard Air-Line R. Co. v. Wells, roo Fla. 1631, 131 So. 777 (1931); Re Billings-Sheridan Bus Line, P.U.R. rg28B, 816 (rg28). But see Wabash, C. \& W. R. Co.v. Commerce Commission ex rel, Jefferson S. W. R, Co., 309 Ill. 412, I4 I N.E. 2 I2 (1923). 
cantly, the term, "public interest," has not been interpreted as an equivalent to the promotion of the general welfare. ${ }^{x 0}$

Contrary to early expectations ${ }^{I r}$ based upon experience with the public utility legislation, the courts have never engaged in a process of defining this discretionary standard as used in the Communications Act; nor have they placed any serious limitation on it. Public interest, interpreted from case to case, has more and more approached the concept of general welfare. ${ }^{x z}$

A plausible explanation for the difference in the interpretation and application of this standard may result from the difference in the objectives sought in the two types of legislation. Public utility legislation was designed to protect consumers from unfair rates in fields where the tendency toward monopoly and oligopoly was considered inherent. ${ }^{\mathrm{x}} \mathrm{A}$ public authority was given control over rates and services; in return, the utility operators were freed from the rigors of competition and granted officially recognized monopoly positions. ${ }^{14}$

At the time the Radio Act of $1927^{15}$ was proposed, there was no indication that Congress was designing legislation intended to cope with the same kind of monopoly problems that were involved in the utility industries. Conspicuously missing from the Act was the "grandfather" clause, which, used in the public utility legislation, gave preference to operators already in the field. The clause was an express concession to the economic interests of existing operators. Its absence in the radio legislation suggests that Congress intended the Commission to exercise its discretion in the licensing of broadcasters without regard to any

ro The courts have not allowed the commissions to exercise authority under this standard not directly related to consumer protection from monopolistic rates or practices. Compare N.Y. Central Securities Co. v. United States, 287 U.S. I2 (Y932), involving an interpretation of the standard as used in Sections $5(2)$ and $200(2)$ of the Interstate Commerce Act, $4 \mathrm{I}$ Stat. 480, $482,494$ ( 1920$), 49$ U.S.C.A. $\$ \S 5(2), 20 a(2)$ (I929). See Hall, State Control of Business through Certificates of Convenience and Necessity $89-93$ (1948).

It is significant to note that the concept of "public interest" in other contexts was primarily challenged when used as a basis for regulation of an industry; cf. Munn v. Illinois, 94 U.S. Ir3 (1876); Nebbia v. New York, 29I U.S. 502 (1934).

II The Federal Radio Commission said in its Second Annual Report (I928) at r66, "To be able to arrive at a precise definition of such a phrase which will foresee all eventualities is manifestly impossible. The phrase will have to be defined by the United States Supreme Court, and this will probably be done by a gradual process of decisions on particular combinations of facts."

"xome of the cases pointed out that it was not an unlimited power. But the only restrictions that emerged were that the Commission could not act unconstitutionally, arbitrarily or capriciously: WOKO, Inc. v. FCC, I53 F. $2 d 6_{23}$ (App. D.C., x945), rev'd on other grounds, 329 U.S. 223 (r946). Compare Yankee Network v. FCC, 107 F. 2d 212 (App. D.C., x939).

${ }_{3}$ See Mosher and Crawford, Public Utility Regulation 93-106 (1933).

Is It is important to note that control over service was only taken to insure effective rate regulation. Since there was to be no competition, the utility operator could frustrate rate regulation by cutting down on the quantity or quality of services offered, thus cutting his costs. If the consumer was to be effectively protected against unfair rates, the regulation had to assure a "dollar's worth for a dollar."

${ }^{25} 44$ Stat. II62-II74 (x927). See note 7, supra. 
vested economic interests. The greater solicitude shown utility operators points up the hesitation with which Congress interfered in industries where there were no physical limitations to prevent the operation of a free-market process. The technological limitations on the number of radio frequencies available, however, precluded even the theoretical existence of free entry into the radio field within a given geographical area. Evidently Congress felt less restraint in regulating a monopoly made necessary by technology than in recognizing a monopoly caused by market imperfections. ${ }^{16}$

The congressional disinclination to recognize or establish any vested economic interests in the radio industry is further evidenced by the provision of the Act requiring every licensee to sign an express disavowal of any property rights in the license issued him. ${ }^{17}$ This provision did not apply to those broadcasters who had obtained licenses prior to the I927 Act. Nevertheless, when the Federal Radio Commission, in its efforts to clear up the congestion on the broadcast bands, refused to issue new licenses to these broadcasters, the courts quashed the claim of an unconstitutional deprivation of property for all time. There was nothing for the broadcasters to own of which they could be deprived, said the courts..$^{18}$

Was the discretion vested in the Communications Commission so broad as to represent an unconstitutional delegation of authority on the part of Congress? ${ }^{29}$ In this regard, the public utility statutes served better than analogies. If Congress could delegate authority to regulate for economic reasons under the standard of public interest, convenience and necessity, certainly the same standard might be used when the delegation was motivated by technological necessity..$^{\circ}$

${ }^{16}$ The Commission early decided that some protection would be given to the broadcasters already in the field. In United States Broadcasting Corp., 2 F.C.C. 208, 236 (1935), the Commission said, "The abstract right of all persons to engage in the business of broadcasting is not absolute, but exists only if their operation will serve public interest, convenience, and necessity. Although the law expressly negatives a vested right in any licensee ... the Federal Radio Commission early in its administration enunciated the principle that true public interest requires that existing stations should not be deprived of broadcasting privileges unless sound reasons of public policy demand such action."

${ }^{17} 48$ Stat. ${ }^{1083}$ (1934), 47 U.S.C.A. $\$ 304$ (Supp., x949).

${ }^{18}$ White v. FRC, 29 F. 2d II 3 (D.C. Ill., I928); United States v. American Bond \& Mortgage Co., 3r F. 2d 448 (D.C. Ill., r929), aff'd 52 F. 2d 3 I8 (C.A. 7th, r93 I), cert. den. 285 U.S. $53^{8}\left(x_{932)}\right.$.

I9 Panama Refining Co. v. Ryan (the Hot Oil cases), 293 U.S. 388 (1935), is the leading case in support of the doctrine that Congress cannot delegate legislative authority without setting down standards for guidance of the delegatee. The doctrine itself has questionable vitality today; cf. Currin v. Wallace, 306 U.S. I (I939); Fahey v. Mallonee, 332 U.S. 245 (1947). At any event, the reasoning of the Hot Oil cases was never applied to the exercise of Commission authority.

${ }^{20}$ The ${ }_{927}$ Act provided that the Commission make a "fair and equitable allocation of broadcasting facilities," 44 Stat. I 66 (r927), and in some early cases this provision was used as one basis of the Commission's power to delete stations. FRC v. Nelson Bros. Bond \& Mortgage Co., 289 U.S. 266 (1933). However, since there were always other considerations present in addition to that of fair allocation, the more comprehensive public interest standard was usually cited by the courts as the basis of Commission authority. 
The courts upheld this view. ${ }^{2 x}$

Still another constitutional hurdle was to be met. The "product" of the radio industry was "speech." The cry of censorship, coupled with the free speech provision of the First Amendment, was to plague the Commission again and again. While this administrative body was given a very wide discretion as to what the service should be, it was not given a carte blanche to ignore the First Amendment. The Act specifically declared that the Commission was not to have the power of censorship, or of interfering with the right of free speech. ${ }^{22}$ How it was possible to regulate in the public interest, convenience, and necessity without impinging on the force of the provision against censorship and the First Amendment was a problem left to the Commission - and the courts.

The Commission early contended for the right to consider program content in the issuance of licenses. ${ }^{23} \mathrm{In}$ an early court test, the licensee's claim of censorship was briefly dismissed, the court saying,

There has been no attempt on the part of the Commission to subject any part of appellant's broadcasting matter to scrutiny prior to its release. In considering the question whether the public interest, convenience, or necessity will be served by a renewal ... the Commission has merely ... [taken] note of appellant's past conduct, which is not censorship. ${ }^{24}$

The fact that the broadcast material was considered inimical to the public health no doubt accounted for the short shrift made of the claim of censorship. ${ }^{25}$ Even when the Commission chose one applicant over another on the basis of better program service, the industry's complaints were not too loud. Somehow a

${ }^{21}$ National Broadcasting Co.v. United States, 3 I9 U.S. I9० (1943); Chicago Federation of Labor v. FRC, 4 I F. 2d 422 (App. D.C., 1930); City of New York v. FRC, 36 F. 2d xr5 (App. D.C., I929); General Electric Co. v. FRC, 3I F. 2d 630 (App. D.C., I929); White v. FRC, 29 F. 2 d II3 (D.C. Ill., I928).

${ }^{22} 48$ Stat. Iogr (I934), as amended, 47 U.S.C.A. $\$ 326$ (Supp.; r949).

${ }^{23}$ In 1928 , the FRC said: "The Commission believes it is entitled to consider program service rendered by the various applicants, to compare them, and to favor those which render the best service." FRC, Annual Report to Congress (I928), at I6r. See Technical Radio Laboratory v. FRC, 36 F. 2d IIr, Ir4 (App. D.C., I929).

${ }^{24}$ KFKB Broadcasting Ass'n, Inc. v. FRC, 47 F. 2 d 670, 672 (App. D.C., I93I). The broadcaster had been prescribing treatment to listeners, the treatment urged being the use of patent medicines manufactured by the broadcaster. In Trinity Methodist Church, South v. FRC, 62 F. 2 d $85^{\circ}$ (App. D.C., 1932), the broadcaster had used his station to emit vituperative attacks on the Catholic Church and on the local government. Again the court had little difficulty in dismissing the claim of a violation of free speech. This was only a reasonable exercise of governmental control for the public good.

On the strength of these court tests, the Commission has declared other program categories to be against public interest: Adelaide L. Carrell, 7 F.C.C. 219, 222 (1939) (astrological predictions); Scroggin \& Co. Bank, I F.C.C. I94, I95 (I935) (advice on marriage); Bremer Broadcasting Co., 2 F.C.C. 79, 83 (I935) (advice on health).

2s It is to be noted that even when the scope of authority broadened from that of traffic policeman, the Commission was never limited by the doctrine of the Hot Oil cases, 293 U.S. 388 (1935). The precedents of the public utility cases and the earlier radio cases settled the matter as far as the courts were concerned. 
selection had to be made, and if one applicant promised to do more for the public interest, convenience and necessity than another applicant, the former probably deserved the license. ${ }^{26}$

When the Commission actually began to hand down rules and proscriptions for the broadcasters to follow on penalty of being denied renewal of their licenses, the industry became aggressive. ${ }^{27}$ The broadcasters contended that the prime function of radio regulation was to prevent interference on the frequencies, and that under the guise of public interest, convenience and necessity, the Commission was causing interference-interference with free speech. ${ }^{28}$

Not all of the broadcasters' ire was directed at the Commission's supposed interference with free speech. The Commission was beginning to use "public interest" in the layman's sense. ${ }^{29}$ Licenses were issued or denied not merely on a comparison of the technical and financial abilities of the various applicants, but upon a determination of whether the services of this particular broadcaster would benefit the American people. The Commission had travelled far from its original role of airwaves traffic policeman. Control over radio had become more than regulation based on technological necessity; it had become regulation of conduct, and the basis was but emerging.

In I949, the Commission issued a report on editorializing by broadcasters, which, although modifying the former ban on editorializing under the Mayflower $^{30}$ doctrine, was hardly a complete relinquishment of the Commission's control over radio editorials. Recently, a potential broadcaster found that the Commission could deny him a license on the basis of his previous activities as a newspaper publisher. A review in some detail of the Report on Editorializing ${ }^{3 \mathrm{x}}$ and the recent decision in Mansfield Journal Co. v. Federal Communications

${ }^{26}$ Hearings pursuant to $\S 3^{\circ} 7$ (c) of S. $3285,73 \mathrm{~d}$ Cong. 2nd Sess., at A23 (1934), 48 Stat. ro83(c) (r934), as amended 47 U.S.C.A. 307 (c) (I949).

${ }^{27}$ The flamboyant trade paper "Broadcasting" had this to say about one of the Commission's decisions: "Jot down July, I946 A.D. (in the year of our Lord) as the day the F.C.C. took jurisdiction over God." Broadcasting, p. 4 (July 29, I946). See generally, Miller, op. cit. supra, note $\mathbf{r}$.

Louis G. Caldwell points up the change in reaction on the part of the broadcasters in his article, Developments in Federal Regulation of Broadcasting, Variety Radio Directory $940-48$ (r939-40). The change in the Commission's approach is traced in Rosenberg, Program Content-A Criterion of Public Interest in F.C.C. Licensing, 2 Western Pol. Q. 375 (1949).

${ }^{28}$ Broadcasting, p. $I_{4}$ (Sept. 22, I947); Caldwell, F.C.C.-Comments on the Report of the Staff of the Attorney General's Committee on Administrative Law, 8 Geo. Wash. L. Rev. 749 (r940).

29 The courts approved with significant expressions: National Broadcasting Co. v. United States, 3 Ig U.S. IgO, 2 I6 (I943) (the Commission has the burden of determining the composition of radio communications); Simmons v. FCC, 169 F. 2d 670, 672 (App. D.C., 1948) (the Commission must determine that programming is "tailored to the particular needs of the community").

${ }^{30}$ Mayflower Broadcasting Corp., 8 F.C.C. 333 (r94r).

${ }^{31}$ FCC, Report on Editorializing by Licensees (I949). It is set out in full in I R.R. 9r: 201 (1949). 
Commission $n^{32}$ can illustrate the current use and broad reach of the concept of public interest, convenience and necessity.

\section{The Report on Editorializing}

Never had an uncontested dictum secured more complete compliance or caused greater discontent than that of the now celebrated Mayflower case. In I94I, the Mayflower Broadcasting Corporation applied for a renewal of its WAAB (Boston) license. The licensee had broadcast the editorial views of the station's owners during the period preceding the application. The decision condemned such editorializing, saying,

A truly free radio cannot be used to advocate the causes of the licensee. It cannot be used to support the candidacies of his friends. It cannot be devoted to the support of principles he happens to regard most favorably. In brief, the broadcaster cannot be an advocate. 33 .

The condemnation was in strong tones, but the license was granted; the condemnation was dictum.

This particular kind of dictum, however, had all the force of well-settled law as far as the licensees were concerned. This was dictum issued by a board possessing the power to withhold broadcasting licenses, and during the eight years of the Mayflower doctrine's existence, it was obeyed. ${ }^{34}$ Even when the station owners began a full-dress attack on the doctrine's validity, they used as their battleground the press and Congress, rather than seeking a direct court test. ${ }^{3}$;

The extreme reluctance of the broadcasters to press for a court test may be accounted for by more than a fear of action by the Commission. The ban on editorializing in no way interfered with a station's ability to show a profit. On the contrary, it left more time for commercial programs. ${ }^{36}$ Further, those licensees that were interested in putting forth a particular point of view on controversial matters were still able to select the commentators for commercial programs. ${ }^{37}$

32 I80 F. 2 d 28 (App. D.C., 1950).

33 Mayflower Broadcasting Corp., 8 F.C.C. 333, 340 (r94x).

34 Broadcasting, p. 13 (Jan. 20, I947). Obedience sometimes took unique shape: WGN, the Chicago Tribune station, read Tribune editorials as part of the advertising for the newspaper.

3s See Hearings before Subcommittee of Committee on Interstate and Foreign Commerce on S. I333, 80th Cong. Ist Sess., at I I r, I 26 (r947); N.Y. Times, p. 54, col. 7 (Apr. 20, 1948). The attack on the editorializing ban was supported by many newspaper columnists: see Lawrence, "Questions of Editorial Opinions on Radio," N.Y. Sun, p. 29, col. I (Mar. 3, 1948). But see I20 New Republic 28 (June 20, I949).

${ }^{36}$ White, The American Radio 177 (I947).

37 Variety, pp. 26, 30 (July 25, I945); Stewart, Radio Commentators and Free Speech, I4 Common Sense 32 (Aug., 1945). Charles Siepmann suggests that the modification of the Mayflower doctrine may be a good thing since it will bring out into the open opinions now smoked under by the use of commentators. Siepmann, Shall Radio Take Sides? I66 Nation 2ro (Feb. 2I, r948). The Report on Editorializing did not specifically encompass the commentator problem: see text infra, at 87 . 
Much more difficult to explain is the motivation of the Commission in enunciating the ban on editorializing. In The American Radio, Llewellyn White suggests:

Some of them [the Commissioners] sincerely believed with the people in government that, inasmuch as the media of mass communication seemed to be falling into the hands of fewer and fewer men and inasmuch as these few, for natural economic reasons, seemed to be drawing farther away from the masses they served on fundamental public issues, they might better withdraw from the field of advocacy altogether and make the facilities available to all shades of opinion..$^{38}$

Whether or not these motives were clearly in the minds of the majority of the Commissioners, it is evident that the Commission was no longer satisfied to act merely as a traffic policeman.

It was the consensus of those who approved of the ban on editorializing that since the Commission was required to select from among many applicants, an obligation arose to see that radio did not become a mouthpiece for particular economic, social or moral philosophies. ${ }^{39}$ Democratic theory would require that licenses be granted either in equal ratios to men of varied philosophies, or granted only on condition that no man use his license to expound only his particular philosophy. Since the former would require a probe into personal ideologies, the latter course was a more feasible alternative. $4^{\circ}$

When the National Association of Broadcasters, under the militant leadership of Justin Miller, ${ }^{43}$ began its all-out fight against the extended powers of the Commission, the Mayflower doctrine seemed a perfect rallying point. Serious doubts had been entertained by others than the station owners as to the propriety of the ban..$^{2}$ When the NAB petitioned for a hearing on the Mayflower doctrine, the Commission acceded.43 On June 8, I949, the Report on Editorializing was handed down. One exuberant observer called this "the greatest single

${ }^{38}$ White, The American Radio 177 (I947).

39 Heffron, Free Air or Hot Air, 50 Commonweal 334 (July 15, r949); American Civil Liberties Union, Should Radio Have an Editorial Policy? (1948); 120 New Republic 27 (June 20, 1949). The broadcasters, at least on the record, did not approve, according to a survey. N.Y. Times, Section 2, p. II, col. 4 (Dec. 28, 1947).

${ }^{10} \mathrm{It}$ was further argued that it would be almost impossible to find licensees of varied philosophies, since radio had become big business. The Commission estimates that $\$ r_{33}, 000$ is the average initial outlay necessary for a regional station in a city over 50,000 population. More important, profits from broadcasting had become tremendous. Blue Book, at 49 . Thus, ran the argument, there had to be safeguards preventing the one and only economic class represented in radio from foisting all their ideas upon the radio audiences. See text infra, at $9 x$.

4I See White, The American Radio 84-85 (1947).

4 Siepmann, Shall Radio Take Sides?, 166 Nation 210 (Feb. 21, I948); Heffron, Should Radio be as Free as the Press? 47 Commonweal 466 (Feb. 20, 1948).

${ }_{43}$ The hearings were ordered ${ }^{\prime \prime} I$ ) To determine whether the expression of editorial opinions by ... licensees . . . is consistent with their obligations to operate their stations in the public interest. 2) To determine the relationship between any such editorial expression and the affirmative obligation of the licensees to insure that a fair and equal presentation of all sides of controversial issues is made over their facilities." FCC, Report on Editorializing, at I (rg49). 
victory in behalf of freedom of expression ... since ... the editorial freedom of newspapers [was confirmed]." 44

Licensees could editorialize, but the Commission was not ready to surrender the field completely to the broadcasters. The right of the public to be informed is the "foundation stone of the American system of broadcasting," 45 and the broadcasters' adherence to this precept was to be judged in terms of "overall fairness." ${ }^{6} 6$

The fact that the broadcaster possessed great economic resources was no justification for preventing him from editorializing. The private advocate might possess these same advantages. ${ }^{47}$ Station owners who advocate their private views may still meet the requirement of "overall fairness," for,

The duty to operate in the public interest is no esoteric mystery, but is essentially a duty to operate a radio station with good judgment and good faith guided by a reasonable regard for the interests of the community to be served..$^{48}$

The Commission had a frank answer to the complaint that this standard of "fairness" would violate the First Amendment:

Any regulation of radio, especially a system of limited licenses, is in a real sense an abridgement of the inherent freedom of persons to express themselves by means of radio communication. It is, however, a necessary and constitutional abridgement in order to prevent chaotic interference from destroying ... this medium.... The most significant meaning of freedom of the radio is the right of the American people to listen ... free from any governmental dictation as to what they can or cannot hear and free alike from similar restraints by private licensees. 49

44 Statement by Justin Miller, 53 Time, No. 24, p. 53 (June 13, r949).

45 FCC, Report on Editorializing, at 2 (1949).

${ }^{66}$ The Commission cited as precedent its decision in United Broadcasting Co., ro F.C.C. $5{ }_{5}$ (x945). The case arose when the United Auto Workers protested that station WHKC of Columbus, Ohio, owned by United Broadcasting Co., had refused to sell them time on many occasions and had unfairly censored scripts when the union was allowed to broadcast. The licensee and the union later came to terms, and the reported case granted a joint motion that the Commission adopt the agreed-upon statement of policy and dismiss the proceedings. Shortly after this case the NAB dropped from its Code the provision recommending that no broadcaster sell time for the presentation of controversial issues.

47 Compare Heffron, Free Air or Hot Air, 50 Commonweal 334 (July 15, 1949).

$48 \mathrm{FCC}$, Report on Editorializing, at 7 (1949). The quotation is taken from the decision in Northern Corp. (WMEX), 4 R.R. 333, 339 (I948).

49 FCC, Report on Editorializing, at 8 (I949). The Commission quoted at length from the decision in Associated Press v. United States, 326 U.S. I (r945), where Justice Black said, at 20: "It would be strange indeed, however, if the grave concern for freedom of the press which prompted adoption of the First Amendment should be read as a command that the government was without power to protect that freedom. ... Freedom of the press from governmental interference under the First Amendment does not sanction repression of that freedom by private interests." Compare Associated Press v. NLRB, 3or U.S. ro3 (I937).

The Commission hastened to recognize that radio is within the First Amendment, as determined (in a dictum) in United States v. Paramount Pictures, Inc., 334 U.S. I31, I66 (I948). 
Although the question of "commentator regulation" was not specifically covered in the report, it seems to fall within the "fairness" test..$^{\circ}$ Nothing said in the report will prevent the Commission from considering the character of sponsored news commentaries in future licensing proceedings. If it is found that a licensee has allowed or encouraged commentaries without regard to the "right of the public to be informed," renewal can be denied.sx

Reaction to this modification of the Mayflower doctrine was favorable..$^{52}$ The Commission had lifted a ban that was too easily analogized to a government ban on newspaper editorials. The standard of "overall fairness" indicated that the concept of public interest had lost none of its former vitality. If the broad test of "fairness" is administered conscientiously, it will permit the Commission to promote fair discussion of controversial issues without leading to government determination of the content of such discussion. ${ }^{53}$

Most important, the Commission seems finally to have faced the spectre of the First Amendment and held its ground. The report candidly recognizes that radio is neither a railroad nor a newspaper, that freedom of speech can best be protected in radio by effective government controls, and that these controls are but a means by which to secure a more effective freedom. ${ }^{54}$

5o If there is to be no requirement that the station provide for fairness as to its sponsored commentator programs, the whole Mayflower controversy would seem to be a tempest in a teapot. It is much too easy for the biased licensee to avoid any risk of being charged with unfairness simply by choosing a commentator who "thinks right." See Stewart, Radio Commentators and Free Speech, I4 Common Sense 32 (Aug., 1945).

sx Commissioner Jones, dissenting, criticized the majority for "disregarding" the commentator problem. He urged definite standards to cover licensees and commentators. Missing, however, was any enumeration of these standards. Query as to whether any such enumeration could be made which would not be censorship. See text infra, at $9 r$.

5253 Time, No. 24, p. 53 (June I3, I949); 33 Newsweek, No. 24, p. 5 I (June I3, I949); Heffron, Free Air or Hot Air, 50 Commonweal 334 (July 15, r949); 27 U.S. News, No. 10, p. 22 (Sept. 2, I949). But see I20 New Republic 27 (June 20, I949).

53 A note in 35 Cornell L.Q. 574 (I950) urges that the Administrative Procedure Act, 60 Stat. 238 (1946), 5 U.S.C.A. § 1002 (a) (3) (Supp., 1949), requires the setting up of standards. The note further argues that the denial of renewal based on "unfair" editorializing on the part of the licensee is similar to ex post facto legislation unless such standards are set up. But as in Commissioner Jones' dissent (note $5 \mathrm{I}$, supra), there is conspicuously absent any determination of what those standards should be, as well as any discussion of how such standards would be effective without comprising detailed government control over what can be said over the airwaves.

The Commission applied the "fairness" test in a reprimand delivered to station WLIB, New York City. The station had broadcast a series of programs advocating a national Fair Employment Practices Commission, without soliciting other views on the subject. In a letter made public by the Commission the station was told that it must "seek out, and encourage the broadcast of opposing views." Chicago Tribune, p. I8, col. 4 (April r4, r950).

54 The analogy to the action of the Department of Justice in Associated Press v. United States, 326 U.S. I (I945), would seem sound. Furthermore, since it is the government that determines who is to operate a radio station, the duty to protect free speech actually goes far beyond the duty inferred from the Sherman Act as regards newspapers. 


\section{The Mansfield Journal Case}

Under Section 3 II of the Communications Act, the Commission is to refuse a license to any person who "has been finally adjudged guilty by a Federal court of unlawfully monopolizing or attempting unlawfully to monopolize, radio communications ... or to have been using unfair methods of competition." 55 Section 313 gives courts authority to revoke licenses of radio broadcasters upon their being found guilty of antitrust violations in regard to radio..$^{6}$ No other provision of the Act relates to monopoly in express terms. By normal rules of statutory interpretation, the Commission would seem to be precluded from denying a license to one engaged in monopolistic practices unless he had been convicted, and then only if the conviction was for activities in radio communications..$^{57}$ The Commission, however, has not felt itself so limited, and its authority in this respect was affirmed in the Mansfield Journal case.

The Mansfield Journal Company had applied for AM and FM licenses, both of which were denied by the Commission on the basis of the applicant's previous activities as the sole newspaper in the town of Mansfield, Ohio..$^{8}$ These activities included coercion of advertisers to prevent them from using the existing radio station, WMAN, refusal to carry the program log of the radio station, and refusing to print any save unfavorable comments about the station. Since WMAN was the only other medium of mass communication in the town, the Commission concluded that the applicant's conduct was for the purpose of securing a monopoly of mass advertising and news dissemination. Under these circumstances, the Commission determined that a grant of a broadcasting license would be inconsistent with the public interest. The Court of Appeals for the District of Columbia saw no usurpation of authority by the Commission and affirmed the administrative body's decision.

In regard to the Commission's authority to deal with problems of radio monopoly without prior antitrust convictions, the court had clear precedent. The Networks ${ }^{59}$ case, testing the validity of the Commission's chain broadcasting regulations, had gone much farther than the facts of the case required in upholding the regulatory body's authority to prevent monopolization of the radio field, Justice Frankfurter declaring for the Court,

Nothing in the provisions or history of the Act lends support to the inference that the Commission was denied the power to refuse a license to a station not operating in the "public interest" merely because its misconduct happened to be an unconvicted violation of the anti-trust laws..$^{60}$

s5 48 Stat. ro86 (I934), 47 U.S.C.A. § 3 II (Supp., I949).

${ }^{56} 48$ Stat. ro87 (I934), 47 U.S.C.A. \& 3 r3 (Supp., I949).

57 Compare Continental Casualty Co. v. United States, 374 U.S. 527 (1942).

${ }^{8}$ Fostoria Broadcasting Co., 3 R.R. 20r4a (r948).

59 National Broadcasting Co. v. United States, 3 I9 U.S. Igo (r943).

60 Ibid., at 223. 
But the Mansfield Journal had engaged in monopolistic practices as a newspaper and not as a broadcasting licensee; hence the question of monopoly within the radio field was not really involved. In fact, the applicant's actions were intended to bring about not radio monopoly, but no radio at all; he sought to attain a monopoly of Mansfield's advertising, by running Station WMAN out of business. ${ }^{6 r}$ The court of appeals seemed unaware that it was going beyond the broad dicta of the Networks case when it announced:

The fact that a policy against monopoly has been made the subject of criminal sanction by Congress as to certain activities does not preclude an administrative agency charged with furthering the public interest from holding the general policy of Congress to be applicable to questions arising in the proper discharge of its duties. . . . Monopoly in the mass communication of news and advertising is contrary to the public interest, even if not in terms proscribed by the antitrust laws. ${ }^{62}$

Only in passing did the court point out that the character of the applicant is specifically a relevant consideration under the terms of the Act. ${ }^{63}$ This consideration in itself would seem to allow the Commission to deny licenses to applicants engaging in unfair business practices. That the Commission and the court preferred to rest their decisions on the broader test of public interest suggests that the goal is not only to forestall monopoly in radio, but also to give the Commission discretion to prevent or discourage monopoly in the other agencies of mass communication. ${ }^{64}$ This view is further indicated by a Commission state-

6x There is no finding by either the Commission or the court that applicant was even considering applying for a radio license at the time he engaged in his monopolistic conduct. Consequently, the relation of his conduct to radio is hardly more than incidental.

${ }^{62}$ 180 F. 2d 28, 33 (App. D.C., I950).

${ }^{63}$ Section 308(b) of the Act, 48 Stat. 1084 (r934), 47 U.S.C.A. $\$ 308$ (b) (Supp., r949) declares that the Commission may investigate the "citizenship, character, and financial, technical and other qualifications of the applicant to operate the station." In Mester v. United States, 7o F. Supp. II8 (N.Y., 1947), the court upheld the Commission's action in refusing to approve a transfer of a license which would give the appellant majority ownership of the station. The appellant had had many difficulties with government agencies as to weight shortages, O.P.A. violations and misleading labeling, from which the Commission deduced that appellant did not possess a sense of public responsibility necessary to operate a radio station in the public interest. But see Hugh O. Jones, II F.C.C. $\operatorname{Ir}_{3} 8$ ( 1947 ), in which the Commission granted a license to applicant who had disregarded local liquor and gambling laws for an extended period of time.

${ }^{64}$ The decision could have been based on any of three grounds:

a. Since the Mansfield Journal was the only newspaper in town, and since it had attempted to acquire an advertising monopoly, the grant of a radio license would enhance the possibilities of achieving such a monopoly, perhaps even to the extent of driving WMAN out of business entirely. However, the thrust of the decision does not indicate such a basis, no mention being made of the effect a new station would have on WMAN. It has not been a consistent policy of the Commission to consider the economic effect on existing licensees in their grant of licenses to new broadcasters. FCC v. Sanders Bros. Radio Station, 309 U.S. 470 (1940). But see FCC, An Economic Study of Standard Broadcasting (r947).

b. Since appellant had engaged in monopolistic conduct before, it was probable that he would do it again, a variation of the "bad man" theory. If this were the basis, it would seem 
ment to the effect that monopolistic conduct by the motion picture studios, even though occurring wholly within the motion picture field, would be an important factor in determining the studios' qualifications as broadcasting licensees. ${ }^{65}$ When this statement is compared with a recent Commission decision granting a license to an applicant known to be violating the local liquor and gambling laws, ${ }^{6}$ it becomes evident that the Commission is interested not in serving as a general law-enforcement agency, but rather as an influence in the promotion of full freedom in all media of mass communication.

The result in the Mansfield Journal case seems sound, despite the reliance placed on the classification of the applicant's conduct as monopolistic. Irrespective of whether the Mansfield Journal had engaged in any activities in violation of the antitrust laws, the past conduct of the applicant and the potential evil of concentrating further control over communications into the hands of the applicant afforded a substantial basis for determining that the public interest would not be served by the grant of a license.

\section{The Unique Position of the Commission}

Recounting the expansion of the standard of public interest is much easier than accounting for it, since neither the courts nor the Commission have ever discussed the unique regulatory position of this administrative body. Radio regulation, aimed at preventing technological interference, necessarily brought about a limitation of entry into the field. Radio is not as free as the press, and to say that it should be is either to ignore the limitation on the availability of frequencies or to suggest a return to the chaos existing prior to 1927.

The Commission cannot confine its activities solely to prevention of technological interference any more than the utility commissions can restrict their authority to rate regulation. ${ }^{67}$ Restriction on entry into the radio field secures the station owner against new competition. Consequently, the broadcaster's incentive to improve and increase the service rendered is largely confined to the fear of losing revenue to the other existing stations. In towns where only one or

that the authority of the Commission to consider character would have come in for more discussion than it did. Compare Mester v. United States, 7o F. Supp. II8 (N.Y., r947).

c. The Commission is the only regulatory body concerned with communications, and it should do all in its power to see that monopoly does not exist in any form of communications, whether that form is normally under the control of the Commission or not. In addition to the language quoted in the text, the court gave further indications that this was the rationale by its citation of Southern Steamship Co. v. NLRB, 3 I6 U.S. 3 I (1942), in which the Supreme Court decided that the Board was powerless to order reemployment of sailors who had been accused of mutiny by their employers. Although no mutiny charges had been brought under the mutiny statute, the Supreme Court declared that the Board was not "commissioned to effectuate the policies of the Labor Relations Act so single-mindedly that it may wholly ignore other and equally important Congressional objectives" (p. 47).

${ }^{65}$ Reply by Commission to Questions of Senate Interstate Commerce Committee, I RR 9I: 225 (I949).

${ }^{66}$ Hugh O. Jones, II F.C.C. II38 (r947). $\quad{ }^{67}$ Note $1_{4}$, supra. 
two stations are licensed, the licensee's incentive can be almost nonexistent. It thus becomes the Commission's duty to promote the quality of service normally produced by competition; the Commission must construct the standard of public interest as a substitute for the "public interest" which automatically asserts itself in the "free market."

As indicated, the similarity of radio to the public utility is limited. A rough railroad ride or a high electric bill can be independently judged as such by the public; to some extent, a barometer is provided as to what regulation is necessary. But a broadcaster who slants the news can determine how the people shall judge, and a broadcaster who fosters racial prejudice can entrench the American dilemma. ${ }^{69}$ Consequently, the determination of what regulation is necessary to promote freedom of radio may often require a judgment as to what the public values should be, rather than what they are.

Most important, the "product" of radio is speech, and it is the dilemma of the Commission to enforce freedom of speech without becoming a government censor. Under such circumstances, there can be no well defined standards. From case to case, from situation to situation, the regulatory body must determine how the public interest can best be served. Since the "product" is speech, the fact that radio is largely controlled by a single economic class, which shares identical or similar economic and political philosophies, can assume a relevance not present in public utility regulation..$^{70}$ Effective radio regulation requires listener protection from ideas and ideals foisted upon them without opportunity to hear "the other side."

If the Commission is to use value judgments in determining who is to broadcast and what are to be the standards of programming, an open expression of these policies is essential to prevent perversion of this potentially dangerous control. Further, a frank recognition of the extent of this control and the basis for its existence can forestall broadcaster attacks on the Commission's authority. The report revising the Mayflower doctrine is commendable in this respect. The possibility of "government" radio is considerably lessened and

${ }^{68}$ Some broadcasters have claimed that the only restriction on the availability of station frequencies is the one the government "decrees." At the beginning of r950 there were 2,835 AM and FM stations on the air, with 358 applications pending before the Commission. Broadcasting, p. 88 (Feb. $\mathrm{r} 3, \mathrm{I} 95^{\circ}$ ). There is no reliable estimate of how many additional stations can be accommodated now or in the near future. The fact remains that a brief perusal of any volume of the Commission Reports clearly indicates that there are more applicants than there are stations, and that it is the Commission that decides which of the applicants will get the license.

${ }^{69}$ The Commission is now investigating charges that G. A. Richards, owner of stations in Los Angeles, Detroit and Cleveland, instructed his newscasters to slant the news and inject racial and religious bias into their newscasts. Evidence proves that, at Richards' order, a newscaster implied that Mrs. Roosevelt's automobile accident in 1945 was caused by her drunkenness. There is little question that many people believed this report.

70 See Llewellyn White's statement quoted in text supra, at 85 . The cost of setting up a radio station (Note 40 supra) is some substantiation of the claim that radio stations are controlled by one economic class, unrepresentative of the listening public. 
that of radio becoming an even more effective means of mass communication is considerably enhanced if the Commission is conscious and open about the authority exercised. ${ }^{x x}$

The standard of public interest, convenience and necessity gives the Commission the discretion necessary to carry out its obligations. Its use provides the conceptual frame for regulation required by the concomitant factors of technological limitations on the number of stations and the desire to prevent one-sided control over an important means of mass communication.

\section{ANCIENT RULES AND MODERN TRUSTS}

\section{I}

Motivated by a deep distrust of the ability of future generations to preserve property interests, testators frequently attempt to retain control of their wealth and to project their authority over its use and distribution far beyond the grave. ${ }^{\mathrm{I}}$ Not only does the law furnish elaborate devices by which such control may be carried out, but the possibility of large tax savings provides a strong additional incentive for the creation of multiple generation gifts. ${ }^{2}$ The number of successive estates which may be set up is limited by the rule against perpetuities. However, since future interests are now invariably created by the use of trusts, ${ }^{3}$ the restraints on land at which this rule was originally directed are

${ }^{7 x}$ Advocates of government-controlled radio in Great Britain point with scorn at the American system whereby private advertisers set the standards of radio content. In his recent book, British Broadcasting (I950), R. H. Coase quotes one supporter of the British system as saying (at I33), "It is one of the many advantages of the public ownership and control of the radio that certain standards have been maintained. We have kept out the advertiser of pills and corn-plasters and suchlike who holds the American radio in the hollow of his hand. ..."

I The ability to control property after death has been referred to as "the greatest latitude ever given in the history of the world to the volition and caprice of the individual." Maine, Village Communities 42 (r889). For a comprehensive outline of the economic and psychological motives for which donors "transmute their volition into dead hand restraints" and of the general community objectives in policing such restraints, consult McDougal and Haber, Property, Wealth, Land $246-49$ (1948). The various legal devices by which these restrictions may be carried out are discussed in Scott, Control of Property By the Dead, 65 U. of Pa. L. Rev. 527, 632 (I917).

2 See text infra p. ror.

${ }^{3}$ As the basis of wealth shifted from land to intangible property interests, the possibilities of dissipation and mismanagement of family holdings increased, and the use of the trust as a device for the transmission of wealth from generation to generation eventually became almost universal.

The English Property Act of 1925 made all future interests equitable interests. Now the only legal freehold estate in English law is the fee simple absolute in possession. If a series of future interests is created, the legal fee simple title vests in the life tenant in possession in trust for all subsequent beneficial owners. Cheshire, Modern Real Property 470-7I (6th ed. I949).

In Illinois, where it is necessary for the conservation, preservation, or protection of real estate subject to legal future interests, a remainderman may petition a court of equity to appoint a trustee with authority to sell, mortgage, or lease the property or to take any other measures necessary for its preservation. Ill. Rev. Stat. (Bar ed. I948) c. 22, $\$ 50$. 